\title{
Biological activity of soils under systems of organic farming, agroforestry and pasture in the Amazon ${ }^{1}$
}

\author{
Atividade biológica de solos em sistemas de cultivo orgânico, agroflorestal e \\ pastagem na Amazônia
}

\author{
Irene Ferro Silva ${ }^{2}$, Sebastião Elviro de Araújo Neto ${ }^{3 *}$ e Jorge Ferreira Kusdra ${ }^{3}$
}

\begin{abstract}
The aim of this work was to evaluate biological indicators of soils used under the systems of organic farming, agroforestry and pasture in the south western part of the Amazon region of Brazil. The experiment was carried out at the Seridó Ecological Site, located in Rio Branco, in the state of Acre, Brazil. The experimental design was completely randomised, with five treatments (land-use systems) and six replications, with each replication consisting of four single samples. The systems of land use evaluated were: 1) native forest (control); 2) agroforestry (AFS); 3) pasture; 4) intercropped passion fruit, maize, cassava, pineapple and forage peanut; and 5) intercropped passion fruit, maize, cassava, pineapple and tropical kudzu. It was found that organic farming systems intercropped with kudzu resulted in smaller losses of $\mathrm{C}_{-} \mathrm{CO}_{2}$ through edaphic respiration, and a greater accumulation of microbial biomass carbon. The intercropped organic farming system which included the forage peanut resulted in a greater loss than retention of carbon in the soil at a depth of 5-10 cm. Soil under the agroforestry system was equivalent to the soil of the control (native forest) in relation to the release and retention of carbon through biological activity. At a depth of 5-10 cm, soils under pasture presented similar microbial biomass to those under organic cultivation intercropped with tropical kudzu. However, at that depth, soils under pasture presented greater microbial biomass than those under natural forest, agroforestry or organic cultivation intercropped with forage peanut.
\end{abstract}

Key words: Organic production. Carbon dynamics. Ground cover.

RESUMO - O objetivo deste trabalho foi avaliar indicadores biológicos de solos sob uso em sistemas de cultivo orgânico, agroflorestal e com pastagem no sudoeste da Amazônia. O experimento foi conduzido no Sítio Ecológico Seridó, localizado em Rio Branco, Acre. O delineamento experimental foi o inteiramente casualizado com cinco tratamentos (sistemas de uso do solo) e seis repetições sendo que cada repetição foi composta por quatro amostras simples. Os sistemas de uso do solo avaliados foram: 1) floresta nativa (controle); 2) sistema agroflorestal (SAF); 3) pastagem; 4) consórcio de maracujá, milho, mandioca, abacaxi e amendoim forrageiro; e 5) consórcio de maracujá, milho, mandioca, abacaxi e puerária. Verificou-se que o sistema de cultivo orgânico consorciado com participação de puerária resultou em menor perda de C-CO por respiração edáfica e maior acúmulo de carbono na biomassa microbiana. O sistema de cultivo orgânico consorciado ${ }^{2}$ com participação de amendoim forrageiro resultou em maior perda do que retenção de carbono na camada de 5 a $10 \mathrm{~cm}$ de profundidade do solo. O solo com sistema agroflorestal foi equivalente ao controle com uso florestal no que se refere à liberação e retenção de carbono pela atividade biológica. Na profundidade de 5 a $10 \mathrm{~cm}$ os solos com pastagem apresentaram biomassa microbiana similar aos em cultivo orgânico consorciado com participação de puerária. Porém, nesta mesma profundidade, os solos com pastagem apresentaram maior biomassa microbiana do que os com uso florestal, agroflorestal e em cultivo orgânico consorciado com participação de amendoim forrageiro.

Palavras-chave: Produção orgânica. Dinâmica do carbono. Cobertura de solo.

\footnotetext{
*Autor para correspondência

${ }^{1}$ Recebido para publicação em 02/08/2012; aprovado em 06/01/2014

Trabalho realizado como exigência da disciplina de Agroecologia do Programa de Pós-Graduação em Produção Vegetal da UFAC com financiamento de bolsas CAPES e CNPq concedida aos autores

${ }^{2}$ Programa de Pós-graduação em Produção Vegetal, Universidade Federal do Acre, Rio Branco-AC, Brasil, daireneagro@ hotmail.com

${ }^{3}$ Centro de Ciências Biológicas e da Natureza, Universidade Federal do Acre, Rio Branco-AC, Brasil, selviro2000@yahoo.com.br; kusdra@globo.com
} 


\section{INTRODUCTION}

Brazil is one of the countries with the greatest diversity of plantresources, with these being concentrated mainly in the Amazon. However, deforestation of this region as a result of anthropic activities has caused changes not only in the vegetation cover, but also in the soils and the availability of nutrients to plants. Therefore, it is increasingly necessary to adopt agricultural technologies and sustainable forests which are capable of reducing environmental damage.

One of the biological phenomena that can occur with the substitution of forests by agricultural areas is a reduction of microbial biomass carbon in the soil (MATSUOKA; MENDES; LOUREIRO, 2003). However, organic farming and systems of agroforestry are considered to be sustainable models that may promote a greater retention of carbon in the soil, minimising its loss to the atmosphere.

Microbial biomass is a biological indicator considered sensitive to changes in the soil due to different usage systems (MATIAS et al., 2009), and is greater in soils having greater plant diversity (LORANGER-MERCIRISA et al., 2006; XUE- MEI et al., 2007). Moreover, it can provide benefits in monitoring environmental changes, both natural and resulting from agricultural use, being an important tool in planning correct land usage and in the evaluation of management practices (COSTA; GOEDERT; SOUZA, 2006).

Basal respiration is a widely-used parameter in quantifying microbial activity and indirectly, the quality of the soil. It represents the oxidation of organic matter into $\mathrm{CO}_{2}$ (ANDERSON; DOMSCH, 1978), having a close relationship with the abiotic conditions of the soil, including humidity, temperature and aeration, which are influenced by the rate of decomposition of the organic matter (SEVERINO et al., 2004). Organic matter, besides contributing to reducing the negative impacts that may arise from the intensive and successive management of cultivated areas (CARDOSO et al., 2009 CUNHA et al., 2011), also increases the biodiversity of the soil (FREITAS et al., 2011).

Microbial activity tends to be greater on the surface of the soil, the greater the quantity and quality of plant residue that makes up the deposited organic material (FIALHO et al., 2006; PIMENTEL et al., 2006). However, attention should be paid when interpreting the values of this biological indicator, as high microbial activity does not always indicate desirable conditions. It may mean, for example, release of nutrients for plants in the short term and the loss of organic carbon from the soil to the atmosphere in the long term (ARAÚJO; GOEDERT; LACERDA, 2007). According to Freitas et al. (2011) microbial carbon and $\mathrm{CO}_{2}$ emissions present increases of 100 to $200 \%$ in the organic cultivation of vines, compared to conventional cultivation.

This work aimed to evaluate biological soil indicators under organic, agroforestry and pasture cropping systems in the south western region of the Amazon.

\section{MATERIAL AND METHODS}

An experiment designed to fulfill the aim of this work was carried out from November of 2009 to November of 2011 on the Seridó Ecological Site, at Rio Branco, in the Brazilian state of Acre (AC), located at latitude $9^{\circ} 53^{\prime} 16^{\prime \prime} \mathrm{S}$ and longitude $67^{\circ} 49^{\prime} 11^{\prime \prime} \mathrm{W}$, at an altitude of $150 \mathrm{~m}$.

The climate in the region is hot and humid and of type Am according to the Köppen classification, with annual average temperatures of around $24.5{ }^{\circ} \mathrm{C}$, a relative humidity of $84 \%$ and an annual rainfall ranging from 1700 to $2400 \mathrm{~mm}$.

A completely randomised design was employed, with five treatments and six replications. Each replication was made up of four single samples. The treatments consisted of the following systems of land use: 1) native forest, considered as control, as it is the closest to a state of equilibrium; 2) agroforestry system (AFS) established for 18 years, and mainly composed of: açaí (Euterpe precatoria), cupuaçu (Theobroma grandiflorum), guava (Psidium guajava), abiu (Pouteria caimito) and jucá (Caesalpinia ferrea var. ferrea); 3) pasture with 20 years of usage, rotated every 30 days and with on average 15 days under beefcattle; 4) intercropped passion fruit (Passiflora edulis $f$ flavicarpa), maize (Zea mays), cassava (Manihot esculenta), pineapple (Ananas comosus) and forage peanut (Arachis pintoi), established for 26 months; 5) intercropped passion fruit, maize, cassava, pineapple and tropical kudzu (Pueraria phaseoloides), also established for 26 months. The intercropping treatments, referred to as 1 and 2, differ in terms of plant diversity only in relation to the species used as ground cover, having forage peanut in the first and kudzu in the second.

The edaphic and soil basal respiration, microbial biomass and metabolic quotient were evaluated. For evaluation of the basal respiration, microbial biomass and metabolic quotient the soil was divided into two depths, 0-5 cm and 5-10 cm, and the collected samples were evaluated separately.

The edaphic respiration was determined with use of static chambers, made of tubes of rigid polyvinyl chloride (PVC), $200 \mathrm{~mm}$ in diameter and $50 \mathrm{~cm}$ high, inserted into 
each area at a depth of about $5 \mathrm{~cm}$. A plastic container was placed into each chamber containing $30 \mathrm{~mL}$ of $0.5 \mathrm{~N} \mathrm{NaOH}$ solution for capturing the $\mathrm{CO}_{2}$, and in five of these, considered as control (blank), the base was sealed with plastic in order to prevent the $\mathrm{CO}_{2}$ from being captured from the soil by the $\mathrm{NaOH}$ solution. After incubation for 48 hours, the $\mathrm{NaOH}$, collected from the containers inside the tubes, was titrated with $0.5 \mathrm{~N} \mathrm{HCl}$ plus $2 \mathrm{~mL}$ of $10 \%(\mathrm{~m} / \mathrm{v}) \mathrm{BaCl}_{2}$ to precipitate the carbonate, with 2 drops of $1 \%(\mathrm{~m} / \mathrm{v})$ phenolphthalein as indicator (CAMPOS, 2006; OLIVEROS, 2008).

The amount of $\mathrm{C}-\mathrm{CO}_{2}$ emitted per unit surface area was calculated as per equation 1 below, proposed by Anderson (1982).

$E R=((B-V) N E) /(A . T)$

where: $\mathrm{ER}=$ edaphic respiration expressed in $\mathrm{mg} \mathrm{C}-\mathrm{CO}_{2}$ $\mathrm{m}^{-2} \mathrm{~h}^{-1} ; \mathrm{B}=$ volume in $\mathrm{ml}$ of $\mathrm{HCl}$ used in the blank test (control); $\mathrm{V}=$ volume in $\mathrm{ml}$ of $\mathrm{HCl}$ used in the sample exposed to the soil; $\mathrm{N}=$ normality of the $\mathrm{HCl} ; \mathrm{E}=$ gram equivalent of the carbon; $\mathrm{A}=$ area in $\mathrm{m}^{2}$ of the sampled soil surface; $\mathrm{T}=$ period of incubation in hours.

Basal soil respiration was determined with $100 \mathrm{~g}$ of soil, sifted and incubated in sealed glass flasks containing $20 \mathrm{~mL}$ of $0.5 \mathrm{~N} \mathrm{NaOH}$ to capture the $\mathrm{CO}_{2}$ released by the sample. After incubating for seven days, the $\mathrm{NaOH}$, collected from the containers inside the flasks, was titrated with $0.5 \mathrm{~N} \mathrm{HCl}$ plus $2 \mathrm{~mL}$ of $10 \%$ $(\mathrm{m} / \mathrm{v}) \mathrm{BaCl}_{2}$ to precipitate the carbonate, with 2 drops of $1 \%(\mathrm{~m} / \mathrm{v})$ phenolphthalein as indicator (SILVA; AZEVEDO; DE-POLLI, 2007).

The amount of $\mathrm{C}-\mathrm{CO}_{2}$ released by the samples was calculated using equation 2 below, proposed by Stotzky (1965).

$B R=((B-V) \cdot N \cdot E \cdot F U \cdot F D \cdot 10) / T$

where: $\mathrm{BR}=$ basal respiration expressed in $\mathrm{mg} \mathrm{C}-\mathrm{CO}_{2}$ $\mathrm{kg}^{-1}$ soil $\mathrm{h}^{-1} ; \mathrm{B}=$ volume in $\mathrm{ml}$ of $\mathrm{HCl}$ used in the blank test (control); $\mathrm{V}=$ volume in $\mathrm{ml}$ of $\mathrm{HCl}$ used in the sample exposed to the soil; $\mathrm{N}=$ normality of the $\mathrm{HCl}$; $\mathrm{E}=$ gram equivalent of the carbon; $\mathrm{HF}=$ humidity factor, obtained from the quotient of wet and dry soil weights; DF $=$ dilution factor, obtained from the quotient of the volumes of $\mathrm{NaOH}$ used in titration and incubation; $10=$ correction factor, $\mathrm{g}$ to $\mathrm{kg}$; $\mathrm{T}=$ period of incubation in hours.

The microbial biomass was obtained by the Anderson and Domsch method of induced respiration (1978), using as substrate $0.5 \mathrm{~g}$ of refined sugar mixed with $100 \mathrm{~g}$ of sifted soil, and incubated in sealed glass flasks containing $20 \mathrm{ml}$ of 0.5 $\mathrm{N} \mathrm{NaOH}$ in order to capture the $\mathrm{CO}_{2}$ released by the sample. After incubating for 4 hours the $\mathrm{NaOH}$, collected from the containers inside the flasks, was titrated with $0.5 \mathrm{~N}$
$\mathrm{HCl}$ plus $2 \mathrm{~mL}$ of $10 \%(\mathrm{~m} / \mathrm{v}) \mathrm{BaCl}_{2}$ to precipitate the carbonate, with 2 drops of $1 \%(\mathrm{~m} / \mathrm{v})$ phenolphthalein as indicator. The $\mathrm{C}-\mathrm{CO}_{2}$ released by the soil samples using the method of substrate-induced respiration was measured in the same way as for the basal respiration. The microbial biomass was calculated by equation 3 :

$y=40,04 x+0,37$

where $\mathrm{y}=$ microbial biomass in $\mathrm{mg} \mathrm{C}$-mic $\mathrm{kg}^{-1}$ soil and $\mathrm{x}=\mathrm{mg} \mathrm{C}-\mathrm{CO}_{2} \mathrm{~kg}^{-1}$ soil $\mathrm{h}^{-1}$ released through respiration induced by the addition of glucose.

The soil metabolic quotient $\left(\mathrm{qCO}_{2}\right)$ was obtained as recommended by Anderson and Domsch (1990), from the ratio between the results for basal respiration (BR) and for microbial biomass (MB) of the same sample, i.e. $\mathrm{qCO}_{2}=\mathrm{BR} / \mathrm{MB}$.

Subsequently, variance analysis was carried out on the original and/or transformed data and when the F-value showed there was a difference between the treatments, their means were compared by the Scott-Knott test. The nonparametric Kruskal-Wallis test was used as an alternative to statistical analysis for those variables in which normality of errors and/or homogeneity of variances were not seen, and also where data transformation, able to meet these assumptions of the variance analysis, was not possible.

\section{RESULTS AND DISCUSSION}

Edaphic respiration did not differ $(p>0.05)$ between the soils under natural forest, AFS, pasture or intercrop 1; however it was higher $(\mathrm{p}<0.05)$ than under intercrop 2 (Table 1). As intercrops 1 and 2 differed only in respect of their cover crops, in comparing the five systems of land use, the kudzu used in intercrop 2 would appear to have been the main plant species responsible for ensuring a lower release of $\mathrm{CO}_{2}$ from the soil through respiration by invertebrates of the edaphic fauna, microorganisms and plant roots. According to Sundarapandian and Kirthiga (2011) the differences in soil respiration observed in different systems of land use can be attributed to factors such as the structure and composition of the vegetation, the density and biomass of the soil organisms and the physico-chemical characteristics of the soil. The kudzu used as cover crop may therefore have played a decisive role in the lower value of edaphic respiration seen in the soil of intercrop 2 .

The basal respiration of the soil, at depths of $0-5 \mathrm{~cm}$ and $5-10 \mathrm{~cm}$, showed different responses in relation to the systems of land use. While at the depth of $0-5 \mathrm{~cm}$ less release of microbial $\mathrm{C}-\mathrm{CO}_{2}$ was seen for intercrop1 $(\mathrm{p}<0.05)$, this situation occurred at a depth of 5 to $10 \mathrm{~cm}$ in 
soils under native forest and agroforestry (Table 1). These results indicate that there is less microbial activity in topsoils under intercropping systems involving the forage peanut, and at greater depths in soils under forests and systems of agroforestry.

The high basal soil respiration observed under the intercropping of kudzu at a depth of 0-5 cm may be related to the productivity of biomass $\left(10.2 \mathrm{~kg} \mathrm{ha}^{-1}\right)$ and to the higher levels of $\mathrm{C}, \mathrm{N}$ and carbohydrates of this leguminous plant (DINESH et al., 2004).

The greater microbial activity at a depth of 5 to $10 \mathrm{~cm}$ in soil covered with forage peanut than with kudzu, was also observed by Duda et al. (2003) who related this result to the higher levels of microbial $\mathrm{P}$ provided by the forage peanut.
In addition to presenting lower edaphic respiration, intercrop 2 was also, among the systems evaluated, that which enabled greater carbon retention in the microbial biomass at both depths $(\mathrm{p}<0.05)$, being equal to that of pasture ( $p>0.05)$ only at a depth of 5 to $10 \mathrm{~cm}$ (Table 2).

The best performance for intercrop 2 in relation to the other systems of land use, with regard to the retention of microbial biomass carbon and the minimisation of its loss to the atmosphere by the topsoil $(0-5 \mathrm{~cm})$, may be due to the ample ground cover and production of phytomass by the kudzu, which in the case of the present work, reached a total dry biomass of 23,993 $\mathrm{t} \mathrm{ha}^{-1} \mathrm{yr}^{-1}$ (CAMPOS, 2011). Furthermore, the kudzu attenuates fluctuations in the temperature and humidity of the soil (PERIN et al., 2002),

Table 1 - Basal and edaphic respiration of soils under natural forest and systems of organic farming (intercrop1 and 2), agroforestry (AFS) and pasture in the south-west Amazon. Seridó Ecological Site, Rio Branco, Acre, 2012

\begin{tabular}{|c|c|c|c|}
\hline \multirow{3}{*}{ System of land use } & \multirow{3}{*}{$\begin{array}{l}\text { Edaphic Respiration } \\
\left(\mathrm{mg} \mathrm{C}-\mathrm{CO}_{2} \mathrm{~m}^{-2} \mathrm{~h}^{-1}\right)\end{array}$} & \multicolumn{2}{|c|}{ Basal Respiration } \\
\hline & & \multicolumn{2}{|c|}{$\left(\mathrm{mg} \mathrm{C}-\mathrm{CO}_{2} \mathrm{~kg}^{-1}\right.$ soil h$\left.^{-1}\right)$} \\
\hline & & $0-5 \mathrm{~cm}$ & $5-10 \mathrm{~cm}$ \\
\hline Forest & $63.71 \mathrm{a}^{(1)}$ & $1.12 \mathrm{a}^{(2)}$ & $0.42 \mathrm{~d}$ \\
\hline AFS & $70.16 \mathrm{a}$ & $0.97 \mathrm{a}$ & $0.33 \mathrm{~d}$ \\
\hline Pasture & $70.77 \mathrm{a}$ & $1.12 \mathrm{a}$ & $0.79 \mathrm{~b}$ \\
\hline Intercrop $1^{(3)}$ & $67.82 \mathrm{a}$ & $0.56 \mathrm{~b}$ & $1.03 \mathrm{a}$ \\
\hline Intercrop $2^{(4)}$ & $55.09 \mathrm{~b}$ & $1.12 \mathrm{a}$ & $0.58 \mathrm{c}$ \\
\hline $\mathrm{CV}(\%)$ & 5.30 & 6.90 & 21.40 \\
\hline
\end{tabular}

${ }^{(1)}$ Averages followed by different lowercase letters in a column differ significantly by the Scott-Knott test at a level of $5 \%$ probability. ${ }^{(2)}$ Original averages with data transformed in arc $\sin \sqrt{ } x / 100^{(1)}$ and ${ }^{3} \sqrt{ } x^{(2)}$ to address the assumptions of the variance analysis. ${ }^{(3)}$ Passion fruit, maize, cassava, pineapple and forage peanut. ${ }^{(4)}$ Passion fruit, maize, cassava, pineapple and kudzu

Table 2 - Microbial biomass and metabolic quotient of soils under native forest and systems of organic farming (intercrop 1 and 2), agroforestry (AFS) and pasture systems in the south-west Amazon. Seridó Ecological Site, Rio Branco, Acre, 2012

\begin{tabular}{lcccc}
\hline \multirow{2}{*}{ System of land use } & \multicolumn{2}{c}{ Soil microbial biomass } & \multicolumn{2}{c}{ Metabolic quotient } \\
\cline { 2 - 5 } & \multicolumn{2}{c}{$\left(\mathrm{mg} \mathrm{C}^{\mathrm{n}} \mathrm{CO}_{2} \mathrm{~g}^{-1} \mathrm{C}-\mathrm{mic}^{-1}\right)$} \\
\cline { 2 - 5 } & $0-5 \mathrm{~cm}$ & $5-10 \mathrm{~cm}$ & $0-5 \mathrm{~cm}$ & $5-10 \mathrm{~cm}$ \\
\hline Forest & $867.17 \mathrm{~b}^{(1)}$ & $416.57 \mathrm{~b}^{(2)}$ & $1.40 \mathrm{a}^{(1)(3)}$ & $1.11 \mathrm{~b}^{(1)}$ \\
Intercrop 1 $^{(4)}$ & $895.38 \mathrm{~b}$ & $416.88 \mathrm{~b}$ & $0.63 \mathrm{~b}$ & $2.52 \mathrm{a}$ \\
Intercrop 2 $^{(5)}$ & $1545.16 \mathrm{a}$ & $779.87 \mathrm{a}$ & $0.78 \mathrm{~b}$ & $0.77 \mathrm{~b}$ \\
AFS & $679.79 \mathrm{~b}$ & $469.96 \mathrm{~b}$ & $1.66 \mathrm{a}$ & $0.89 \mathrm{~b}$ \\
Pasture & $1074.67 \mathrm{~b}$ & $873.81 \mathrm{a}$ & $1.02 \mathrm{a}$ & $0.95 \mathrm{~b}$ \\
$\mathrm{CV}(\%)$ & 27.75 & - & 13.26 & 38.06 \\
\hline
\end{tabular}

${ }^{(1)}$ Averages followed by different lowercase letters in a column differ significantly by the Scott-Knott and Kruskall-Wallis tests at a level of $5 \%$ probability. ${ }^{(2)}$ Original averages with data transformed to address the assumptions of the variance analysis. ${ }^{(4)}$ Passion fruit, maize, cassava, pineapple and forage peanut. ${ }^{(5)}$ Passion fruit, maize, cassava, pineapple and kudzu 
allowing more favourable conditions, suitable for the maintenance of carbon in this system of intercropping.

According to Matias et al. (2009) higher levels of microbial $\mathrm{C}$, such as those observed in the topsoil of the intercropping which included the kudzu, result in a greater temporary immobilisation of nutrients and therefore in less loss of nutrients in the soil-plant system. Taking the forest as a reference, the intercropped organic system with kudzu increased the microbial biomass by $78.18 \%$ in the $0-5 \mathrm{~cm}$ layer and $87.21 \%$ in the 5 to $10 \mathrm{~cm}$ layer.

Comparing the intercropped organic systems, both of which consist of five plant species, with four being the same (passion fruit, maize, cassava and pineapple) and one specific (kudzu or forage peanut), it is seen that intercropping with kudzu showed greater retention of microbial biomass carbon than with pinto peanut at both depths (0-5 and 5-10 cm). However, Duda et al. (2003), when comparing the microbial biomass in soils planted with these same species, noted the superiority of the forage peanut compared to the kudzu. Nevertheless, one should consider that the isolated effect of these cover crops on the carbon of the soil microbial biomass can be very different when they are intercropped with other species, since according to Loranger-Mercirisa (2006), soil microbial activity is greater with the increase in plant diversity, due to the increased availability of nutritional resources to the microorganisms.

The soils used for pasture presented, at a depth of 5-10 cm, a microbial biomass similar to soils in kudzuintercropped organic systems, being however higher than that obtained in soils under native forest, agroforestry systems and intercropped organic systems using the forage peanut. Greater microbial biomass in soils used for grazing has been observed by Asgharipour and Rafiei (2011). According to Alves et al. (2011) the greater microbial activity in areas of pasture happens due to the root systems of these areas being abundant and extensive, presenting continuous renovation and a strong rhizosphere effect.

Although in forest soils there is more plant and microbial diversity (FIALHO et al., 2006; PIMENTEL et al., 2006), this has not resulted in higher amounts of microbial biomass carbon than the other systems of land use evaluated in this work. However, Pôrto et al. (2009) and Cunha et al. (2011) observed greater microbial biomass in soils under conditions of native vegetation than under cropping systems. According to Xue-Mei et al. (2007) the greater microbial activity in soils with native vegetation or cultivated with a great diversity of species occurs due to regularity in the supply of the substrates used by the microbial community.

According to Anderson and Domsch (1990) a higher metabolic quotient represents faster nutrient cycling, and thus greater dynamics of the organic matter and less accumulation of carbon in the soil. In this work, in the $0-5 \mathrm{~cm}$ layer this ratio was lower $(\mathrm{p}<0.05)$ for the intercropped systems 1 and 2 than for the other systems (Table 2). This shows that in soils under systems of intercropping the microbial biomass is more efficient in the use of $\mathrm{C}$, reducing its losses in the form of $\mathrm{CO}_{2}$. However, at a depth of $5-10 \mathrm{~cm}$, the metabolic quotient of soil intercropped with forage peanut was higher $(p<0.05)$ than the other systems of land use. This result shows that at a depth of $5-10 \mathrm{~cm}$ a ground cover of forage peanut provides greater specific respiratory efficiency and a consequent increase in the rate of $\mathrm{C}-\mathrm{CO}_{2}$ release, per unit of biomass.

For all the variables evaluated in this study, the systems of land use employing agroforestry did not differ from those of native forest $(p>0.05)$. This demonstrates that there is some similarity between these systems in terms of the biological conditions related to carbon dynamics.

\section{CONCLUSIONS}

1. Organic systems of cultivation which are intercropped with kudzu result in less loss of $\mathrm{C}-\mathrm{CO}_{2}$ through edaphic respiration, and increased accumulation of microbial biomass carbon than in soils under native forest or agroforestry systems;

2. There is greater loss than retention of carbon at a depth of $5-10 \mathrm{~cm}$ in soils with organic systems intercropped with the forage peanut;

3. The release and retention of carbon through biological activity is similar for soils under native forest and agroforestry systems (AFS);

4. Soils used for pasture, or for organic systems intercropped with kudzu, show greater microbial biomass at a depth of $5-10 \mathrm{~cm}$ than soils under native forest, agroforestry and organic farming systems intercropped with the forage peanut.

\section{ACKNOWLEDGEMENT}

The authors would like to thank CAPES and $\mathrm{CNPq}$ for their financial support of this work.

\section{REFERENCES}

ALVES, T. dos S. et al. Biomassa e atividade microbiana de solo sob vegetação nativa e diferentes sistemas de manejos. Acta Scientiarum. Agronomy, v. 33, n. 2, p. 341-347, 2011.

ANDERSON, J. P. E. Soil respiration. In: PAGE, A. L.; MILLER, R. H.; KEENEY, D. R. (Ed.). Methods of soil analysis: chemical 
and microbiological properties. 2. ed. Madison: American Society of Agronomy, 1982. p. 831-871. v. 2.

ANDERSON, J. P. E; DOMSCH, K. H. A physiological method for the quantitative measurement of microbial biomass in soils. Soil Biology and Biochemistry, v. 10, n. 1, p. 215-221, 1978.

ANDERSON, T. H., DOMSCH, K. H. Application of ecophysiological quotients ( $\mathrm{qCO}$ and $\mathrm{qD}$ ) on microbial biomasses from soils of different cropping histories. Soil Biology and Biochemistry, v. 22, n. 2, p. 251-255, 1990.

ARAÚJO, R.; GOEDERT, W. J.; LACERDA, M. P. C. Qualidade de um solo sob diferentes usos e sob cerrado nativo. Revista Brasileira de Ciência do Solo, , v. 31, n. 5, p. 1099-1108, 2007.

ASGHARIPOUR, M. R.; RAFIEI, M. The effects of land use on biomass and catabolic diversity of soil microbial communities. African Journal of Agricultural Research, v. 6, n. 19 , p. 4607-4612, 2011.

CAMPOS, B. C. Dinâmica do carbono em Latossolo Vermelho sob sistemas de preparo de solo e de culturas. 2006. $188 \mathrm{f}$. Tese (Doutorado em Ciência do Solo) - Centro de Ciências Rurais, Universidade Federal de Santa Maria, Santa Maria, 2006.

CAMPOS, P. A. Cultivo ecológico de maracujá-amarelo consorciado com milho, abacaxi, mandioca e plantas de cobertura do solo. 2011. 48 f. Dissertação (Mestrado em Agronomia) - Programa de Pós-graduação em Agronomia. Universidade Federal do Acre, Rio Branco, 2011.

CARDOSO, E. L. et al.. Atributos biológicos indicadores da qualidade do solo em pastagem cultivada e nativa no Pantanal. Pesquisa Agropecuária Brasileira, v. 44, n. 6, p. 631-637, 2009.

COSTA, E. A.; GOEDERT, W. J.; SOUZA,D. M. Qualidade de solo submetido a sistemas de cultivo com preparo convencional e plantio direto. Pesquisa Agropecuária Brasileira, v. 41, n. 7, p. 1185-1191, 2006.

CUNHA, E. Q. et al. M. Sistemas de preparo do solo e culturas de cobertura na produção orgânica de feijão e milho. II Atributos biológicos do solo. Revista Brasileira de Ciência do Solo, v. 35, n. 2, p. 603-611, 2011.

DINESH, R. et al. Long-term influence of leguminous cover crops on the biochemical properties of a sandy clay loam Fluventic Sulfaquent in a humid tropical region of India. Soil and Tillage Research, v. 77, n. 1, p. 69-77, 2004.

DUDA, G. P. et al. Perennial herbaceous legumes as live soil mulches and their effects on $\mathrm{C}, \mathrm{N}$ and $\mathrm{P}$ of the microbial biomass. Scientia Agricola, v. 60, n. 1, p. 139-147, 2003.

FIALHO, J. S. et al. Indicadores da qualidade do solo em áreas sob vegetação natural e cultivo de bananeiras na Chapada do Apodi-CE. Revista Ciência Agronômica, v. 37, n. 3, p. 250257, 2006.

FREITAS, N. de O. et al. Soil biochemistry and microbial activity in vineyards under conventional and organic management at Northeast Brazil. Scientia Agricola, v. 68, n. 2, p. 223-229, 2011.
LORANGER-MERCIRISA, G. et al. Rapid effects of plant species diversity and identity on soil microbial communities in experimental grassland ecosystems. Soil Biology and Biochemistry, v. 38, n. 8, p. 2336-2343, 2006.

MATIAS, M. C. B. S. et al. Biomassa microbiana e estoques de $\mathrm{C}$ e $\mathrm{N}$ do solo em diferentes sistemas de manejo, no Cerrado do Estado do Piauí. Acta Scientiarum. Agronomy, v. 31, n. 3, p. 517-521, 2009.

MATSUOKA, M.; MENDES, I. C.; LOUREIRO, M. F. Biomassa microbiana e atividade enzimática em solos sob vegetação nativa e sistemas agrícolas anuais e perenes na região de Primavera do Leste (MT). Revista Brasileira de Ciência do Solo, v. 27, n. 3, p. 425-433, 2003.

OLIVEROS, L. F. C. Emissões de $\mathrm{CO}_{2}$ do solo sob preparo convencional e plantio direto em latossolo vermelho do Rio Grande do Sul. 2008. 80 f. Dissertação (Mestrado em Ciências do Solo) - Centro de Ciências Rurais, Universidade Federal de Santa Maria, Santa Maria, 2008.

PERIN, A. et al. Efeito da cobertura viva com leguminosas herbáceas perenes na agregação de um argissolo. Revista Brasileira de Ciência do Solo, v. 26, n. 3, p. 713-720, 2002.

PIMENTEL, M. S. et al. Atributos biológicos do solo sob manejo orgânico de cafeeiro, pastagem e floresta em região do médio Paraíba Fluminense-RJ. Coffee Science, v. 1, n. 2, p. 85-93, 2006.

PÔRTO, M. L. et al.. Indicadores biológicos de qualidade do solo em diferentes sistemas de uso no brejo paraibano. Ciência e Agrotecnologia, v. 33, n. 4, p. 1011-1017, 2009.

SEVERINO, L. S. et al. Mineralização da torta de mamona, esterco bovino e bagaço de cana estimada pela respiração microbiana. Revista de Biologia e Ciências da Terra, v. 5 , n. 1, 2004.

SILVA, E. E. da; AZEVEDO, P. H. S.; DE-POLLI, H. Determinação da respiração basal (RBS) e quociente metabólico do solo (qCO ). Seropédica: Embrapa Agrobiologia, 2007. 4 p. (Comuñicado técnico, 99).

STOTZKY, G. Microbial respiration. In: BLACK, C. A.; EVANS, D. D.; ENSNUNGER, L. E.; VAUTE, J. L.; CLARK, F. E. (Ed.). Methods of soil analysis: chemical and microbiological properties. Madison: American Society of Agronomy, 1965. p. 1550-1572. v. 2.

SUNDARAPANDIAN, S. M.; KIRTHIGA, J. Soil respiration in different land use systems in Puducherry, Journal of Theoretical and Experimental Biology, v. 8, n. 1/2, p. 17-28, 2011.

XUE-MEI, H. et al. Effects of vegetation type on soil microbial community structure and catabolic diversity assessed by polyphasic methods in North China. Journal of Environmental Sciences, v. 19, n. 10, p. 1228-1234, 2007. 